\title{
White sponge naevus: an uncommon oral white lesion
}

\author{
Satya Ranjan Misra, ${ }^{1}$ Rupsa Das, ${ }^{1}$ Swagatika Panda, ${ }^{2}$ Neeta Mohanty ${ }^{2}$
}

'Oral Medicine \& Radiology, Institute of Dental Sciences, Siksha O Anusandhan University, Bhubaneswar, Odisha, India

${ }^{2}$ Oral \& Maxillofacial Pathology, Institute of Dental Sciences, Siksha 0 Anusandhan University, Bhubaneswar, Odisha, India

\section{Correspondence to}

Professor Neeta Mohanty; neetamohanty@soa.ac.in

Accepted 11 November 2021

\section{DESCRIPTION}

White sponge naevus (WSN) is an unusual, benign condition characterised by the presence of diffuse white patches usually seen in the oral mucosa and sometimes in the oesophagus and genital mucosa. ${ }^{1}$ Oral lesions typically occur bilaterally symmetrical, thick, velvety, irregular white patches on the buccal mucosa, labial mucosa, alveolar mucosa, palate, tongue and floor of the mouth which are unscrapable and are either present at birth or appear later in childhood. WSN is generally asymptomatic but the velvety surface irregularities harbour and promote bacterial or fungal growth which can lead to stomatopyrosis. ${ }^{2}$ Since they appear as white patches, they may have a psychological impact on the individuals and a detailed history with meticulous clinical examination is needed to eliminate other oral white lesions. The differential diagnosis of WSN ranges from normal oral mucosal variations, trauma induced white lesions, viral and fungal infections, dermatological diseases manifesting in the oral cavity to oral potentially malignant disorders as summarised in figure $1 .^{3}$ Absence of history of chronic irritation/tissue abuse habits, lack of tell-tale signs like white striae or disappearance on stretching the mucosa, besides the absence of dermatological diseases or any other medical condition in addition to biopsy is required for the diagnosis of these bilaterally symmetrical white patches in the oral cavity. Viral and fungal lesions cannot be clinically differentiated from WSN but empirical antifungal therapy eliminates candidiasis. Although not pathognomonic, histologically hyper-parakeratosis, acanthosis and vacuolisation of keratinocytes having a typical perinuclear eosinophilic condensation is observed in WSN. ${ }^{2}$ Since it is a developmental condition which reappears even after surgery, no treatment is required and only symptomatic relief in case of burning sensation owing to superadded bacterial or fungal infections needs to be treated.

An 18-year-old patient reported with the complaint of burning sensation in the mouth. History revealed the patient could not tolerate spicy food and had to modify his diet to a bland one to get relief for the past 1 month. He has white patches on his buccal mucosae since childhood which have never caused him any problems. He apparently did not have any substance abuse habits or history chronic cheek chewing habit. The patients' medical, dental, personal and family history were unremarkable.

On clinical examination, well-demarcated, symmetrical white patch was present on buccal mucosae bilaterally, almost homogenously white, extending from commissure of lip till the retromolar region of size $4 \times 3 \mathrm{~cm}$ approximately, irregular in shape with well-defined borders with smooth surface and velvety texture which was, rough in consistency, non-tender on palpation and unscrapable. Focal erythematous areas present in the white patches possibly due to masticatory trauma (figure 2). These lesions were not seen anywhere else in the oral cavity or on the body.

Since both frictional hyperkeratosis and morsicatio buccarum are seen clinically as white patches
Check for updates

(C) BMJ Publishing Group Limited 2021. No commercial re-use. See rights and permissions. Published by BMJ.

To cite: Misra SR, Das R Panda $\mathrm{S}$, et al. BMJ Case Rep 2021;14:e246105. doi:10.1136/bcr-2021246105

\section{Differential Diagnosis of White Sponge Naevus}

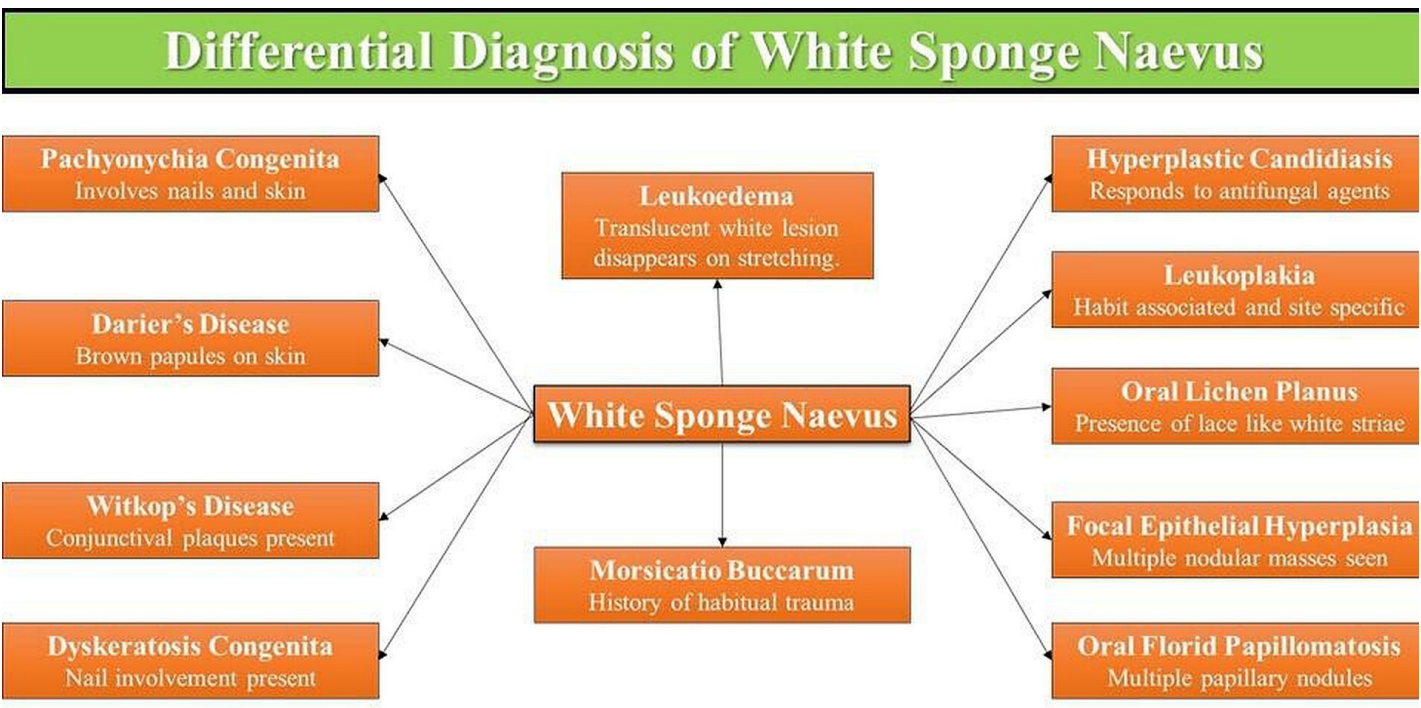

Figure 1 Flow diagram showing the differential diagnosis of white sponge naevus. 


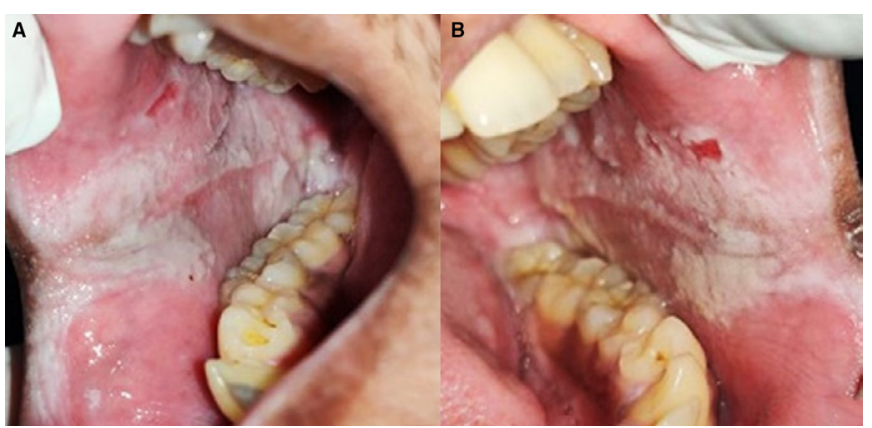

Figure 2 Well-demarcated, symmetrical white patch present on the right $(A)$ and left (B) buccal mucosae, extending from commissure of lip till the retro-molar region of size $4 \times 3 \mathrm{~cm}$ approximately, irregular in shape with well-defined borders with smooth surface and velvety texture.

on the buccal mucosae, associated with chronic trauma, they were excluded by negative history of cheek chewing habit, absence of any malaligned teeth, sharp cusps or buccoverted third molars, besides considering the fact that the white patches extended from the labial commissure to the retromolar region and being present since childhood pointed towards WSN. The presence of focal erythematous areas in the otherwise homogenously

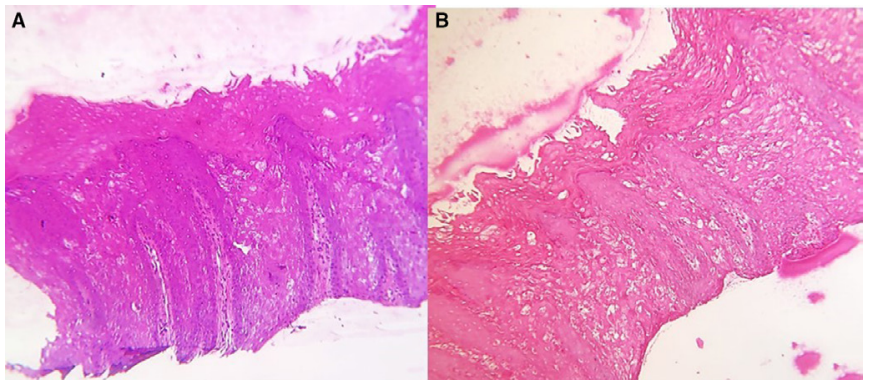

Figure 3 Haematoxylin-eosin-stained section showing hyperparakeratinised acanthotic stratified vacuolated squamous epithelial cells with perinuclear condensation of eosinophilic substances resembling keratin filaments in few epithelial cells, overlying scanty delicately collagenous connective tissue stroma, suggestive of white sponge naevus. Original magnification $10 \times(A)$ and $40 \times(B)$. white patches indicated a possible cause of trauma which inadvertently could happen during mastication. As the symmetrical white patches were present since childhood, not associated with chronic irritation or tissue abuse and the medical history was unremarkable, it was clinically diagnosed as WSN but a biopsy was done to confirm the diagnosis.

Histopathological evaluation revealed hyper-parakeratinised acanthotic stratified squamous epithelium overlying scanty delicately collagenous connective tissue stroma. Epithelial cells showed vacuolation, especially pronounced in the stratum spinosum. Few of the epithelial cells show perinuclear condensation of eosinophilic substances resembling keratin filaments, suggestive of WSN (figure 3). The patient was given 1\% clotrimazole lotion to apply five times a day and he was completely asymptomatic when he was followed up a month later.

\section{Learning points}

- White sponge naevus is a rare developmental oral white lesion.

- It needs to be differentiated from other common oral white lesions especially leukoplakia.

- White sponge naevus must be diagnosed early to avoid unnecessary treatment.

Contributors SRM and RD examined the patient clinically and prepared the manuscript. SP and NM evaluated the biopsy and interpreted the histopathological findings.

Funding The authors have not declared a specific grant for this research from any funding agency in the public, commercial or not-for-profit sectors.

Competing interests None declared.

Patient consent for publication Consent obtained directly from patient(s).

Provenance and peer review Not commissioned; externally peer reviewed.

Case reports provide a valuable learning resource for the scientific community and can indicate areas of interest for future research. They should not be used in isolation to guide treatment choices or public health policy.

\section{REFERENCES}

1 Bezerra KT, Leite TC, Roza ALOC, et al. White sponge nevus: a condition not always clinically suspected. J Cutan Pathol 2020:47:22-6.

2 Alagappan U, Hussain S, Robinson S. 18781 a familial case of white sponge nevus and review of the literature. J Am Acad Dermatol 2020;83:AB220.

3 Elfatoiki FZ, Capatas S, Skali HD, et al. Oral white sponge nevus: an exceptional differential diagnosis in childhood. Case Rep Dermatol Med 2020;2020:9296768.

Copyright 2021 BMJ Publishing Group. All rights reserved. For permission to reuse any of this content visit

https://www.bmj.com/company/products-services/rights-and-licensing/permissions/

BMJ Case Report Fellows may re-use this article for personal use and teaching without any further permission.

Become a Fellow of BMJ Case Reports today and you can:

- Submit as many cases as you like

- Enjoy fast sympathetic peer review and rapid publication of accepted articles

- Access all the published articles

Re-use any of the published material for personal use and teaching without further permission

Customer Service

If you have any further queries about your subscription, please contact our customer services team on +44 (0) 2071111105 or via email at support@bmj.com.

Visit casereports.bmj.com for more articles like this and to become a Fellow 